\title{
Engraftment and Long-Term Expression of Human Fetal Hemopoietic Stem Cells in Sheep Following Transplantation In Utero
}

\author{
Esmail D. Zanjani, " Maria G. Pallavicini, ${ }^{\ddagger}$ Joao L. Ascensao, Allan W. Flake, Richard G. Langlois, Michael Reitsma, \\ F. Roy MacKintosh, Damon Stutes, " Michael R. Harrison," and Mehdi Tavassoli" \\ *Department of Veterans Affairs Medical Center, University of Nevada School of Medicine, Reno, Nevada: ${ }^{\ddagger}$ Lawrence Livermore \\ National Laboratory, Livermore, California; $\$$ University of California School of Medicine, \\ San Francisco, California; and' Department of Veterans Affairs Medical Center, Jackson, Mississippi
}

\begin{abstract}
Hemopoietic stem cells from human fetal liver were transplanted in utero into preimmune fetal sheep (48-54 days of gestation). The fate of donor cells was followed using karyotype analysis, by immunofluorescence labeling with anti-CD antibodies, and by fluorescent in situ hybridization using human-specific DNA probes. Engraftment occurred in 13 of 33 recipients. Of five live born sheep that exhibited chimerism, all expressed human cells in the marrow, whereas three expressed them in blood as well.

Engraftment was multilineage (erythroid, myeloid, and lymphoid) and human hemopoietic progenitors (multipotent colony-forming units, colony-forming units-granulocyte, macrophage, and erythroid burst-forming units) capable of forming colonies in vitro were detected in all five lambs for $>2$ yr. These progenitors responded to human-specific growth factors both in vitro and in vivo. Thus the administration of recombinant human IL-3 and granulocyte macrophage-colony-stimulating factor to chimeric sheep resulted in a 2.1-3.4-fold increase in the relative expression of donor (human) cells. These results demonstrate that the permissive environment of the preimmune fetal sheep provides suitable conditions for the engraftment and long-term multilineage expression of human hemopoietic stem cells in a large animal model. In this model, donor human cells appear to retain certain phenotypic and functional characteristics that can be used to manipulate the size of donor cell pool. (J. Clin. Invest. 1992.89:1178-1188.) Key words: hemopoietic stem cells $\bullet$ in utero transplantation • preimmune fetus $\bullet$ human/ sheep xenograft • fetal liver

\section{Introduction}

Successful engraftment and proliferation/differentiation of transplanted allogeneic hemopoietic stem cells (HSC) ${ }^{1}$ in man

This work was presented in part at the 3-6 May 1991, Annual Meeting of the Association of American Physicians, Seattle, WA.

Address reprint requests to Esmail D. Zanjani, Ph.D., Department of Veterans Affairs Medical Center (151B), 1000 Locust Street, Reno, NV 89520.

Part of this work was done while M. Tavassoli was on a sabbatical leave.

Received for publication 19 September 1991 and in revised form 9 December 1991.

1. Abbreviations used in this paper: BFU-E, erythroid burst-forming unit; CFU-GM, colony-forming unit-granulocyte, macrophage; $C F U$ MIX, multipotent colony-forming unit; Epo, erythropoietin; FISH, fluorescence in situ hybridization; GM-CSF, granulocyte macrophagecolony-stimulating factor; GPA, glycophorin A; GVHD, graft versus host disease; HSC, hemopoietic stem cells; PHA-LCM, PHA-stimulated leukocyte-conditioned medium; PI, propidium iodide; $\mathrm{rHu}$, recombinant human.

The Journal of Clinical Investigation, Inc.

Volume 89, April 1992, 1178-1188 and animals is achieved when the host and graft are immunologically tolerant of each other and/or when the immunological barrier is inoperative $(1,2)$. Tolerance of transplanted allogeneic cells in clinical settings can be achieved using genetically immunodeficient donors/recipients (1-10). Alternatively, immunocompetent recipients can be rendered immunotolerant by using immunosuppressive and/or cytoablative procedures, which may also serve to promote engraftment by donor HSC by eliminating recipient HSC which may compete for homing sites within the bone marrow (1-10). HLA matching and T cell depletion of the donor graft are also useful adjuncts to mitigate development of life-threatening graft versus host disease (GVHD) which may occur during graft rejection $(1,2)$. When applied appropriately, these procedures have been used to achieve chimerism between different species including humanmouse (4-10). Xenogeneic transplantation of human HSC has also been reported in genetically deficient mice $(5-10)$ and in normal mice rendered tolerant by lethal irradiation (4).

A radically different approach to overcome the immune barrier which is operative in hemopoietic cell transplantation is the use of preimmune fetal systems. This approach exploits the fact that during the first and second trimester, recipient fetuses are immunologically "naive" and incapable of mounting a reaction to reject the donor cells, while the preimmune donor cells are also equally incapable of inducing $\operatorname{GVHD}(3,11,12)$. In addition, expansion of the fetal marrow compartment and normal intertissue HSC migration patterns during fetal development may contribute to the receptivity of the marrow environment to transplanted donor cells (see Discussion). Donor HSC transplanted at appropriate gestational ages in utero may home to a relatively "empty" marrow, thus facilitating the establishment of donor hemopoiesis before the seeding of endogenous HSC. Thus, the fetal environment may provide unique opportunities to achieve long-term donor hemopoiesis without the requirement of cytoreduction and immune suppression (3, 12-14).

We have previously described successful transplantation of allogeneic HSC in utero in sheep and monkeys (12-14). Fetal liver-derived sheep HSC transplanted into unrelated preimmune fetal recipients contributed to long-term hemopoietic chimerism for several months after birth $(12,13)$ without development of GVHD. Hemopoietic chimerism was stable and donor stem cells produced erythroid, myeloid, and lymphoid progeny $(3,12-14)$, suggesting that the early gestational age fetuses provide both the ideal donor and recipient environments to achieve HSC engraftment without resorting to cytoablative or immunosuppressive procedures.

Successful long-term establishment of xenogeneic chimeras provides the ultimate test of the basic concept of using preimmune donors and recipients to circumvent the immunological barrier thereby inducing tolerance to foreign cells. We describe here the engraftment and proliferation of human fetal HSC transplanted in utero into a large animal model. We used cyto- 
genetic and culture techniques, DNA-based detection strategies, and flow cytometric analysis of phenotypic markers to detect and monitor the expression of human HSC in recipient sheep. We demonstrate that the permissive environment of the preimmune sheep allows engraftment and long-term $(>2 \mathrm{yr})$ multilineage expression of human HSC.

\section{Methods}

Donor cell preparation and transplantation procedures. The studies were conducted in fetal sheep at 48-54 d of gestation (term: $145 \mathrm{~d}$ ). Dorset Merino ewes (Ovis aries) with confirmed dates of conception were purchased from local suppliers and acclimatized for 10 days before donor cell infusion into the fetus. The microbubble technique used for the in utero transplantation of donor cells has been described previously (13). Briefly, after a 48-h fasting period, maternal ewes were sedated with ketamine $(10 \mathrm{mg} / \mathrm{kg}$, intramuscularly), and received $0.5-$ $1.0 \%$ halothane-oxygen mixture by inhalation via an endotracheal tube. The external jugular vein was cannulated for administration of fluids and antibiotics (penicillin, 2 million U; kanamycin, $400 \mathrm{mg}$ ). The uterus was exposed through a midline incision, and the myometrial layers were divided with electrocautery, leaving the amnion intact. The fetus was manipulated within the amniotic sac and, under direct visualization, donor cells $\left(2 \times 10^{9}-1 \times 10^{10}\right.$ cells $/ \mathrm{kg}$ estimated fetal body wt in $0.5-1.0 \mathrm{ml}$ ) were injected into fetal peritoneal cavity. Uterine and maternal body walls were closed in layers and the ewes, after full recovery, were provided food and water ad lib.

Donor cells were derived from livers of 12-15-wk old male human fetuses obtained from elective therapeutic abortions. Informed consent was obtained from the mother following established institutional and federal guidelines. The sex of the fetus was confirmed by chromosome analysis. Livers were thoroughly rinsed in heparinized Iscove's modified Dulbecco's medium (IMDM) containing 10\% fetal sheep serum and $5 \mathrm{ng} / \mathrm{ml}$ each of recombinant human interleukin-3 and granulocyte macrophage-colony-stimulating factor (GM-CSF)(Genetics Institute, Cambridge, MA). Brief ex vivo incubation of donor cells with IL-3 and GM-CSF has been shown to up modulate stem cell homing receptors and thereby enhance subsequent grafting efficiency of these cells (15). A single cell suspension of mononuclear cells was prepared in the same medium by gentle homogenization of tissue fragments in a handoperated glass homogenizer (Broeck Tissue Grinder; Fisher Scientific Co., Pittsburgh, PA). The cell mixture was centrifuged $(450 \mathrm{~g}, 8 \mathrm{~min}$ ) and the pellet resuspended $\left(2 \times 10^{7}\right.$ cells $\left./ \mathrm{ml}\right)$ in the same medium and incubated at $37^{\circ} \mathrm{C}, 5 \% \mathrm{CO}_{2}$ in humidified air for $12-17.5 \mathrm{~h}$. After incubation, the cell suspension was centrifuged once again and the cells resuspended in the same medium at desired concentrations of 4-20 $\times 10^{7}$ cells $/ \mathrm{ml}$ for injection.

Assessment of donor cell engraftment. The presence of donor cells in hemopoietic tissues of the recipients was sequentially determined at intervals posttransplantation using karyotypic analyses of blood, marrow, and liver hemopoietic cells before and after in vitro cultures, by using flow cytometric analysis of differentiation antigens associated with human hemopoietic subpopulations, and by using fluorescence in situ hybridization (FISH) with DNA probes specific for repeated satellite sequences on human autosomes.

Donor cell engraftment was assessed both before and after birth. Mononuclear cells were obtained by standard procedures(homogenization, flushing of long bones, density gradient separation) from liver, bone marrow, and blood of five recipients at 2 wk after transplantation and from two recipient fetuses each at 4,6 , and $8 \mathrm{wk}$ after donor cell infusion. Blood and marrow hemopoietic mononuclear cells were obtained for analysis from 22 other surviving recipients at 1-2 wk after birth and at about monthly intervals thereafter.

Karyotypic analysis. Karyotypic analyses were used to establish donor cell engraftment in all recipients examined before birth and in all surviving lambs for $\sim 1 \mathrm{yr}$ after transplantation. All samples were analyzed for lymphoid elements expressing human karyotype after stimulation with PHA in the presence of appropriate controls as de- scribed (14). The presence of human hemopoietic progenitors (multipotent colony-forming units [CFU-Mix]; colony-forming units-granulocyte, macrophage [CFU-GM]; erythroid burst-forming units [BFUE]) in liver and bone marrow was determined by karyotyping isolated colonies grown under conditions that selectively promoted the growth of human hemopoietic progenitors in vitro as follows.

Hemopoietic progenitor cell assays. Mononuclear cells from fetal liver $\left(0.2-0.8 \times 10^{5}\right.$ cells $\left./ \mathrm{ml}\right)$, fetal bone marrow $\left(0.25-0.75 \times 10^{5}\right.$ cells $/ \mathrm{ml})$, and newborn/adult bone marrow $\left(0.4-2 \times 10^{5}\right.$ cells $\left./ \mathrm{ml}\right)$ were cultured in methylcellulose as described $(14,16)$. All cultures were established in IMDM with erythropoietin $(2 \mathrm{IU} / \mathrm{ml}$ recombinant human erythropoietin [rHuEpo]). For optimal growth of sheep CFUMix, CFU-GM, and BFU-E, the cultures were supplemented (5\% vol/ vol) with a preparation of PHA-stimulated leukocyte-conditioned medium (sheep PHA-LCM) produced with a mixture of fetal sheep spleen, thymus, liver, and bone marrow cells in IMDM with $2 \%$ fetal sheep serum (14). Optimal growth of human hemopoietic progenitors was achieved with the addition of $5 \mathrm{ng} / \mathrm{ml}$ each of recombinant human IL-3 (rHuIL-3) and GM-CSF to cultures in the absence of PHA-LCM. Colonies were enumerated and processed for karyotyping on days 9, 14, and 19 of incubation $\left(37^{\circ} \mathrm{C}, 5 \% \mathrm{CO}_{2}\right.$ in humidified air).

The methylcellulose culture procedure was also used to establish the relative efficacy of sheep PHA-LCM and/or rHuIL-3/GM-CSF in promoting the growth and development of sheep or human hemopoietic progenitors in vitro. Light density mononuclear cells isolated from adult sheep or human bone marrow aspirates by Ficoll-Hypaque separation (16) were cultured $\left(0.5-1 \times 10^{5}\right.$ cells $\left./ \mathrm{ml}\right)$ with Epo $(2 \mathrm{IU} / \mathrm{ml})$ and varying concentrations of either sheep PHA-LCM $(0.5-20 \% \mathrm{vol} / \mathrm{vol})$ or rHuIL-3/GM-CSF 1-20 ng/ml) as described (16). Colonies were enumerated at 48-h intervals beginning at day 5 of incubation until day 19 of culture.

Karyotypic analysis of hemopoietic colonies. Colonies were identified by type (16), removed from the plates individually, placed in buffered normal saline colcemid solution, mixed, and incubated at $37^{\circ} \mathrm{C}$ for $30 \mathrm{~min}$. The mixture was then centrifuged at $200 \mathrm{~g}$ for $8 \mathrm{~min}$, the supernate was removed, and the cell pellet was slowly resuspended in a solution of prewarmed $\left(37^{\circ} \mathrm{C}\right)$ potassium chloride. The mixture was incubated at $37^{\circ} \mathrm{C}$ for $10 \mathrm{~min}$, spun at $200 \mathrm{~g}$ for $8 \mathrm{~min}$, and the cell pellet resuspended. A fixative solution of $33 \%$ glacial acetic acid in methanol was slowly added to the cell suspension and the cells processed for karyotype analysis as described (14).

Immunofluorescence labeling and flow cytometric analysis. Blood and marrow were processed for immunofluorescence labeling and flow cytometric analysis. Leukocytes were isolated from whole blood by hypotonic lysis of erythrocytes. Whole blood collected in EDTA was added to 15 vol of lysis buffer ( $170 \mathrm{mM} \mathrm{NH}_{4} \mathrm{Cl}, 0.1 \mathrm{mM}$ EDTA, $1 \mathrm{mM}$ $\mathrm{KHCO}_{3}$, at $\mathrm{pH}$ 7.3). Samples were incubated at room temperature for 4-5 min while inverting every $30 \mathrm{~s}$. Cells were pelleted (all centrifugations were for $5 \mathrm{~min}$ at $300 \mathrm{~g}$ ) and the lysis was repeated as necessary until the pellet was relatively free of erythrocytes. Bone marrow was processed in a similar manner to remove contaminating red cells. Isolated blood leukocytes and whole bone marrow were washed once in cold S-Hank's balanced salt solution containing $0.02 \%$ sodium azide. Aliquots of $5 \times 10^{5}$ cells were then resuspended in $100 \mu$ l cold S-HBSS for staining with $\mathrm{CD}$ antibody reagents. Whole blood was fixed with formalin as described previously (17) for glycophorin A (GPA)-based analysis of human erythrocytes.

$\mathrm{CD}$ antigens were labeled using commercial monoclonal antibodies conjugated with either FITC or phycoerythrin (PE). Antibodies specific for CD20 (Leu-16), CD14 (Leu-M3), CD3 (Leu-4), CD4 (Leu-3a), CD16 (Leu-1 1a), CD5 (Leu-1), and CD8 (Leu-2a) were obtained from Becton Dickinson Monoclonals, San Jose, CA. Anti-CD34 conjugated with FITC was a gift of Dr. Peter Lansdorp (Terry Fox Laboratories, Vancouver, Canada). In each sample $20 \mu$ l of the commercial antibody $(25 \mu \mathrm{g} / \mathrm{ml})$ was added to $5 \times 10^{5}$ cells, while the anti-CD34 FITC $(250$ $\mu \mathrm{g} / \mathrm{ml}$ ) was used at $2 \mu \mathrm{l}$ per $5 \times 10^{5}$ cells. Samples were incubated in the presence of the antibody for $30 \mathrm{~min}$ at $4^{\circ} \mathrm{C}$, then washed twice in $5 \mathrm{ml}$ cold PBS without serum protein. Cell viability was assessed by eosin dye exclusion and exceeded $95 \%$ in all samples. Propidium iodide (PI), 
traditionally used for staining, was not used because of the overlap in spectral omission. The cells were then fixed $(0.1 \%$ paraformaldehyde in $\mathrm{PBS}$, at $\mathrm{pH}$ 7.3) for $30 \mathrm{~min}$ at room temperature, washed once in cold PBS, and resuspended in cold PBS (with Hoechst 33342 at a concentration of $15 \mu \mathrm{M}$ ) for flow cytometric analysis. The erythrocyte antigen, glycophorin $\mathrm{A}$, was labeled using either the antibody $10 \mathrm{~F} 7$, or a combination of the two antibodies $6 \mathrm{~A} 7$ and BRIC157, as described previously $(17,18)$.

Fluorescently labeled nucleated cells were analyzed with a dual laser flow cytometer (FACStar Plus, Becton Dickinson, Mountain View, CA). Stained cells were excited with argon lasers adjusted to emit in the UV region and at $488 \mathrm{~nm}$. Signal acquisition was triggered on Hoechst fluorescence collected through a 458-band pass filter. The antibody-linked fluorophores, FITC and phycoerythrin, were excited at $488 \mathrm{~nm}$ and fluorescence emission collected through 514- and 585-nm band pass filters, respectively. Flow cytometric analysis of erythrocytes was performed on a FACScan ${ }^{\oplus}$ flow cytometer using C30 software as described previously (17). Immunofluorescence signals were amplified logarithmically. Approximately 10,000-50,000 cells were analyzed for each sample.

Fluorescence in situ hybridization. FISH with a biotinylated DNA probe (PC190) (19) labeling repeated alpha satellite sequences on human chromosomes was used to detect human cells in sheep blood and marrow. We have shown previously that the $\mathrm{PC} 190$ probe is unreactive with sheep cells and allows detection of human cells present at frequencies of $10^{-4}$ in sheep backgrounds (20). Hybridization conditions are described in Pallavicini et al. (21). Hybridized probe was visualized using FITC-conjugated avidin (DCS grade; Vector Laboratories, Burlingame, CA). DNA was counterstained with PI $(0.25 \mu \mathrm{g} / \mathrm{ml})$ in a fluorescence antifade solution, $p$-phenylenediamine (22). Microscopy was performed on a Zeiss Universal fluorescence microscope equipped with Planneofluor $63 \times 1 / 2.0$ oil objective using a filter set (Omega Optical Inc., Brattleboro; VT) for simultaneous observation of FITC and PI fluorescence.

\section{Results}

Table I summarizes the end results of transplantation in 42 recipients. Cells $\left(10^{8}-10^{9}\right.$ cells $/ \mathrm{kg}$ estimated fetal body $\left.\mathrm{wt}\right)$ from human male fetuses (12-15 weeks of gestation) were transplanted into fetal sheep at 48-54 days of gestation. Recipients were then serially examined for the evidence of engraftment

Table I. Summary of the End Results of Studies in Sheep Receiving Human Fetal Liver HSC Transplantations In Utero

\begin{tabular}{lc}
\hline & $\begin{array}{c}\text { No. of } \\
\text { animals }\end{array}$ \\
\hline Transplanted & 42 \\
Lost to study* & 9 \\
Sacrificed before birth & 11 \\
Evidence of engraftment & 8 \\
Born alive & 22 \\
Chimeric at birth & 5 \\
Blood and marrow & 3 \\
Marrow only & 2 \\
Chimeric at 2 yr & 5 \\
Blood and marrow & 2 \\
Marrow only & 3 \\
Engrafted & 13
\end{tabular}

\footnotetext{
* All losses occurred as the result of surgery. ${ }^{\ddagger}$ This number reflects the total number of recipients that exhibited donor (human) cell engraftment and represents $\sim 40 \%$ of evaluable (i.e., 33 sheep) recipients.
}

during the remainder of gestation and after birth. Of the 42 fetuses who received human cells, 9 were lost to the study due to surgery, 11 were sacrificed before birth for sequential studies, and 22 were allowed to complete gestation and were born alive. Engraftment of human cells was documented in eight recipients who were sacrificed before birth and in five who were born alive. Thus, of the 33 fetuses who could be studied either before or after birth, chimerism could be documented in 13 (40\%). No evidence of GVHD was noted in these animals. The criteria for GVHD were wool loss, diarrhea, and histological evidence of GVHD in lip biopsy. Our protocols also called for skin and liver biopsies when questions existed.

Donor (human) cell engraftment in all recipients sacrificed before birth was determined by karyotypic analysis of blood and other hemopoietic tissues. Karyotyping was also the primary procedure used to establish and monitor the presence of human cells in all recipients after birth. Flow cytometry and FISH were used to confirm and provide further detailed evaluation of donor cell engraftment in the stable chimeric lambs at around one year after birth (15 months after transplantation).

Donor cell engraftment by karyotypic analysis was assessed at two levels. Analysis of metaphases after routine stimulation of peripheral blood and marrow aspirations provided evidence of lymphoid engraftment. Engraftment of donor erythroid and other myeloid cells, however, required karyotyping of hemopoietic colonies formed in cultures of mononuclear cells obtained from liver/spleen and bone marrow of recipients before birth and from bone marrow of transplanted lambs after birth.

In preliminary studies, the effect of different concentrations of sheep PHA-LCM or rHuIL-3 and GM-CSF on colony formation by normal human and sheep hemopoietic mononuclear cells in vitro was determined. Under conditions used here, optimal growth of sheep CFU-Mix, BFU-E, and CFUGM-derived colonies occurred only when adequate concentrations of sheep PHA-LCM, usually 4-7\% (vol/vol), were present. Maximal numbers of colonies were detected by day 9 of incubation. Thereafter, both the number and size of colonies decreased. Few colonies were still present on day 12, but none were observed after 15 days of culture. In these studies, optimal development of human CFU-Mix, BFU-E, and CFU-GM were found to occur in the presence of $5 \mathrm{ng} / \mathrm{ml}$ of IL-3 and GM-CSF. Maximal numbers of colonies were present at about 13-15 days of incubation. About $67-84 \%$ of colonies were still present at day 19 . Similar results were obtained when artificially created mixtures of human and sheep bone marrow mononuclear cells were cultured in the presence of sheep PHA-LCM $(5 \%$ $\mathrm{vol} / \mathrm{vol}$ ) and/or $5 \mathrm{ng} / \mathrm{ml}$ each of rHuIL-3 and GM-CSF. Karyotypic analysis of individual colonies of different types (CFUMix, BFU-E, CFU-GM) grown in mixtures composed of 3-25\% human cells revealed the presence of predominantly $(92 \pm 12 \% ; n=10)$ sheep colonies at day 9 , mostly $(73 \pm 14 \% ; n$ $=10$ ) human colonies on day 14 , and almost exclusively $(98 \pm 24 \% ; n=10)$ human colonies on day 19 of incubation.

In general, as shown in Figs. 1 and 2, concentrations of sheep PHA-LCM (4-7\%) and rHuIL-3/GM-CSF $(5 \mathrm{ng} / \mathrm{ml})$ shown to promote the optimal development of sheep and human colonies in vitro, respectively, had only minimal effect on cells of the other species. At higher concentrations (>20 ng/ $\mathrm{ml}$ ) human cytokines stimulated the formation of some sheep colonies in vitro (data not shown). However, we were not able to achieve optimal growth of sheep colonies in the presence of human cytokines at any concentration $(5-100 \mathrm{ng} / \mathrm{ml})$. Because of toxicity we were unable to test the effect of higher concentra- 

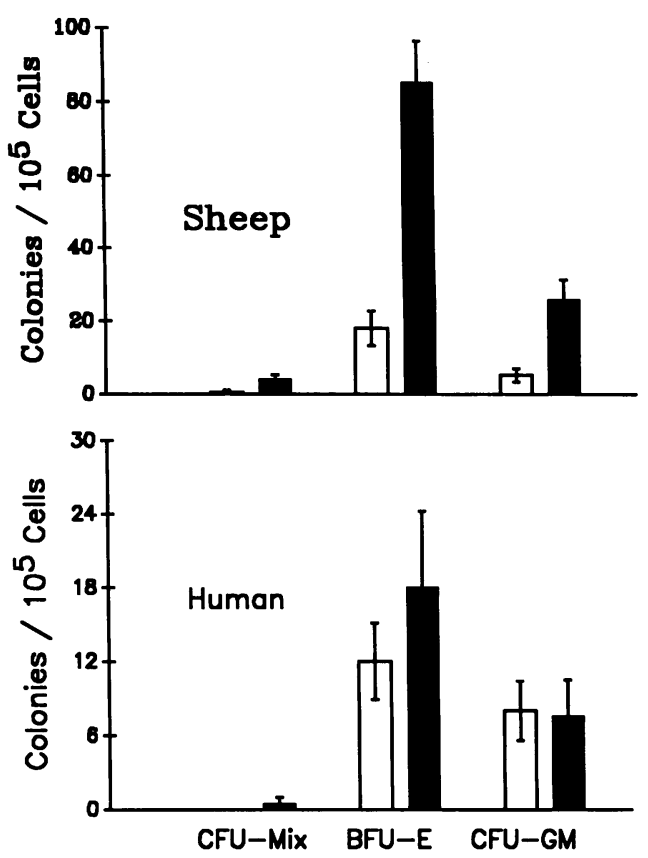

Figure 1. Effect of sheep PHA-LCM on hemopoietic colony formation by normal sheep and human bone marrow cells in vitro. Bone marrow cells $\left(0.4\right.$ and $0.8 \times 10^{5}$ cells $\left./ \mathrm{ml}\right)$ were cultured in methylcellulose in the presence of $2 \mathrm{IU} \mathrm{Epo/ml} \mathrm{with} \mathrm{and} \mathrm{without} \mathrm{PHA-LCM}$ ( $5 \% \mathrm{vol} / \mathrm{vol})$. Cultures were examined at frequent intervals; data from days 9 (sheep) and 15 (human) of incubation are presented. Each value represents mean \pm 1 SEM of results from four separate triplicate experiments, each involving separate normal sheep and human donors. These same donors were also used to obtain results presented in Fig. 2. $\square$, Control; $\mathbf{n},+$ PHA-LCM.
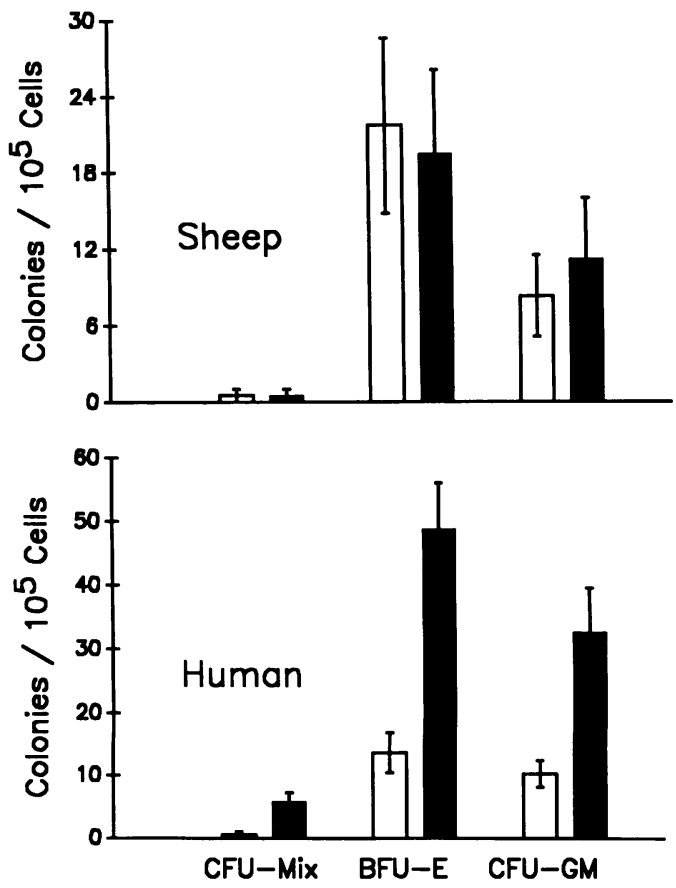

Figure 2. Effect of rHuIL-3 and GM-CSF on hemopoietic colony formation by normal sheep and human bone marrow cells in vitro. See legend to Fig. 1. Cells $\left(0.4\right.$ and $0.8 \times 10^{5}$ cells $\left./ \mathrm{ml}\right)$ were cultured in the presence of $2 \mathrm{IU} \mathrm{Epo} / \mathrm{ml}$ with or without $5 \mathrm{ng} / \mathrm{ml}$ each of IL-3 and GM-CSF. $\square$, Control; $a,+$ rHu IL-3/GM-CSF. tions of sheep PHA-LCM ( $>10 \%$ vol/vol) on human hemopoietic progenitors in vitro. However, at nearly all concentrations tested, sheep PHA-LCM exerted some, albeit statistically insignificant, stimulatory effect on human colony development in vitro. This was most evident with CFU-Mix-derived colonies, a few of which formed in the presence of sheep PHA-LCM (Fig. 1). The effect of sheep PHA-LCM on human BFU-E was manifested by a noticeable increase in the size of these colonies; no effect on CFU-GM was detected.

Therefore, all karyotypic analyses of progenitor-derived colonies presented here were obtained by culturing the cells in the presence of $5 \% \mathrm{vol} / \mathrm{vol}$ sheep PHA-LCM and/or $5 \mathrm{ng} / \mathrm{ml}$ each of rHuIL-3 and GM-CSF. Colonies were enumerated and karyotyped on days 9 and 19 of culture for sheep and human colonies, respectively. These values were used to calculate the percentage of colonies with human karyotypes.

Results summarized in Fig. 3 demonstrate that bone marrow and liver in 8 of 11 fetal recipients sacrificed before birth contained human cells. Human hematopoietic progenitors (CFU-Mix, BFU-E, CFU-GM) comprised about $9 \%$ of the total committed progenitor pool in bone marrow at two weeks after transplantation. The proportion of human cells in bone marrow gradually decreased to $4 \%$ over the next six weeks. Liver contained significantly fewer $(P<0.01)$ donor progenitors at two weeks; no human cells were present in host liver at eight weeks after transplantation. Human cells were not present in the peripheral blood of the sheep fetuses at any time.

All 22 live born lambs were evaluated for the presence of human cells by karyotyping at about two weeks after birth. Five newborn sheep exhibited human cell chimerism. Of these, two lambs expressed human cells in bone marrow only (Table II),

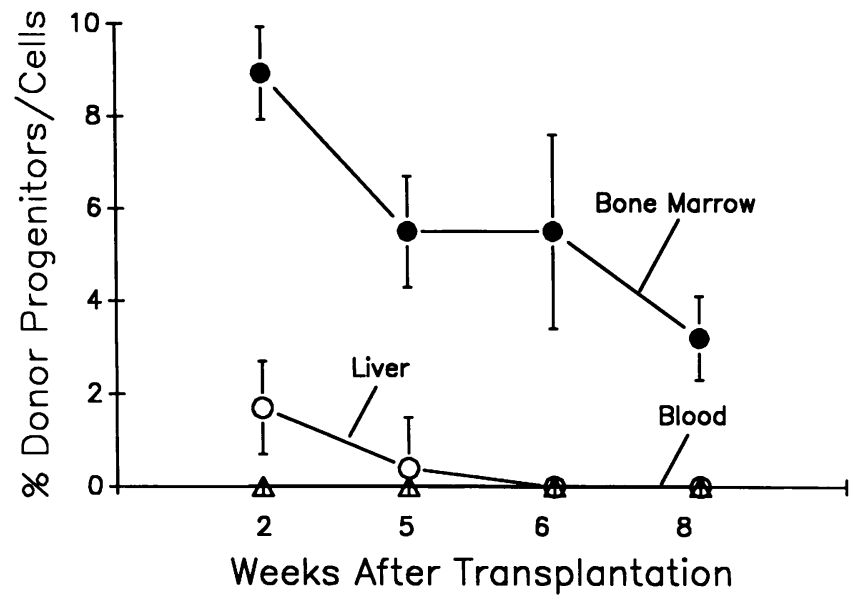

Figure 3. Relative distribution of donor (human) hemopoietic progenitors/cells (determined by karyotyping) in fetal sheep at intervals after transplantation. Bone marrow and liver mononuclear cells $\left(0.2-0.8 \times 10^{5}\right.$ cells $\left./ \mathrm{ml}\right)$ were cultured in multiple methylcellulose plates as described in methods. Total colony numbers were determined on days 9 (mostly sheep) and 19 (primarily human) of incubation; all three progenitor types (CFU-Mix, CFU-GM, and BFU-E) were detected on both days. On day 19 , colonies removed from the plate and individually processed for karyotyping as detailed. Generally, each colony provided three to eight evaluable metaphases. Each value represents the mean of results from 8 of the 11 recipients that exhibited human cell engraftment. For each time point 17-88 colonies were analyzed. No cells exhibiting human karyotype (determined by routine analysis of PHA-stimulated metaphases) were detected in blood of these recipients. 
Table II. Relative Distribution of Donor (Human) Cells in Marrow and Blood of Newborn Lambs at Two Weeks of Age*

\begin{tabular}{lcc}
\hline & \multicolumn{2}{c}{ Percent cells with human karyotype } \\
\cline { 2 - 3 } Animal & Bone marrow & Blood \\
\hline 1219C & 1.8 & 0 \\
1219D & 2.1 & 0 \\
3419 & 3.8 & 1.2 \\
3425 & 1.1 & 0.4 \\
$3425 \mathrm{C}$ & 2.0 & 0.8
\end{tabular}

* All 22 newborns were examined for evidence of donor cell engraftment within the first two weeks of age. The 17 lambs that failed to exhibit donor cell engraftment were evaluated again at 2 and 3.5 months of age; no human cells were detected. ${ }^{\ddagger}$ Bone marrow and peripheral blood cells from each animal were processed for karyotyping by exposure to PHA. The results which were calculated by scoring 450-730 metaphases for each specimen therefore reflect the percentages of donor (human)-derived lymphoid elements in these animals.

and three had human cells in both bone marrow and peripheral blood, with levels ranging from 0.4 to $3.8 \%$ (Table II). The results presented in Table II were obtained by analysis of metaphases obtained after routine PHA stimulation, and as such reflect the relative percentages of human lymphoid cells present in blood and bone marrow of these lambs at this time.

The relative distribution of human erythroid and myeloid progenitors in bone marrow of the five chimeric sheep at two weeks is presented in Table III. Significant numbers of human progenitor-derived colonies were detected in all five lambs. It is interesting to note that the mean \pm 1 SEM of all three progenitor types for all five lambs is $5.2 \pm 1.11 \%$, a value that is similar to the value obtained for the eight chimeric fetal recipients at eight weeks after transplantation (Fig. 3) indicating a possible stabilization of donor cell engraftment in these animals. The multilineage nature of human cell engraftment in chimeric animals was also demonstrated by flow cytometry and FISH.

Table III. Relative Distribution of Donor (Human) Hematopoietic Progenitors in Bone Marrow of Newborn Lambs at Two Weeks of Age*

\begin{tabular}{llrr}
\hline & \multicolumn{3}{c}{ Percent colonies with human karyotype } \\
\cline { 2 - 4 } Animal & CFU-Mix & CFU-GM & \multicolumn{1}{c}{ BFU-E } \\
\hline 1219C & $3.2 \pm 1.5$ & $11.2 \pm 3.6$ & $4.9 \pm 1.8$ \\
1219D & $2.4 \pm 1.0$ & $5.4 \pm 1.7$ & $9.3 \pm 3.0$ \\
3419 & $4.1 \pm 2.1$ & $8.2 \pm 2.9$ & $3.8 \pm 1.0$ \\
3425 & $2.5 \pm 0.3$ & $2.4 \pm 1.1$ & $10.2 \pm 2.1$ \\
$3425 \mathrm{C}$ & $2.7 \pm 1.0$ & $5.1 \pm 0.8$ & $2.6 \pm 0.3$
\end{tabular}

* All 22 newborns were examined for evidence of donor cell engraftment within the first two weeks of age. The 17 lambs that failed to exhibit donor cell engraftment were evaluated again at 2 and 3.5 months of age; no human cells were detected. ${ }^{\ddagger}$ Bone marrow cells from each animal were cultured at three different concentrations with erythropoietin and sheep PHA-LCM with or without rHuIL-3/ GM-CSF. Colonies were obtained at 9 (mostly sheep) and 19 (nearly all human) days of culture for karyotype analysis. Each value represents mean \pm 1 SEM of results obtained from the three cell concentrations each of which were cultured in triplicate; $20-80$ colonies were karyotyped from each culture.
Identification of human surface markers in erythroid cells. Analysis for chimerism of the erythroid lineage was performed by labeling peripheral erythrocytes with monoclonal antibodies specific for the human form of the erythrocyte cell-surface protein, GPA. GPA is a polymorphic cell-surface glycoprotein on human erythrocytes that occurs in two allelic forms, $\mathbf{M}$ and $\mathrm{N}$, which form the basis of the $\mathrm{MN}$ group (18). Previous studies (18) showed rapid divergences of the GPA protein among species, suggesting that $M$ and $N$ antibodies would not recognize the sheep form of this protein. Initially, fixed samples of peripheral blood obtained from a control normal sheep and two chimeric sheep (3419 and 3425C) at about one year after birth were labeled with an antibody, 10F7, which binds both $M$ and $\mathrm{N}$ forms of GPA (18). Flow cytometric analysis confirmed that cells from control sheep did not bind this antibody (i.e., fewer than $0.01 \%$ of the cells showed immunofluorescence values greater than unstained cells). In contrast, samples from sheep 3419 and $3425 \mathrm{C}$ showed small populations of erythrocytes with labeling intensities within $20 \%$ of values obtained from human cells (data not shown). A quantitative analysis of 10,000 cells per sample showed the following proportion of GPA-positive cells in blood from the two transplanted sheep: sheep 3419, 1.0\%; and sheep 3425C, 0.46\%.

Blood samples from the control sheep and sheep 3419 and $3425 \mathrm{C}$ were reanalyzed to confirm the presence of human GPA and determine the $\mathrm{M}, \mathrm{N}$ phenotype of the donor cells. Blood was stained with two additional antibodies, specific for the $\mathbf{M}$ and $\mathrm{N}$ allelic forms of GPA (17). The results, illustrated in Fig. $4, a-c$, confirmed that both animals contained subpopulations of GPA-positive cells. The data generated in Fig. $4 a$ were from an artificial mixture of human (15\%) and sheep (85\%). It may appear visually that the frequency of human cells in this mixture is greater than $15 \%$. In reality, however, the majority of human erythrocytes have zero fluorescence intensity and thus lie directly on the $y$ and $x$ axis. No gates were used for display of data in Fig. $4 a$. The labeling intensity with both antibodies was within $15 \%$ of the expected values for MN phenotype human cells, indicating that the human donor for both sheep was of blood type MN. Both of these antibodies require normal glycosylation patterns for binding (17); thus, these data suggested that the glycosylation patterns of the engrafted erythrocytes might resemble that of normal human cells. Microscopic examination of fixed erythrocytes showed that sheep and human erythrocytes differed substantially in size. With our fixation procedure, human erythrocytes have a mean diameter of 6.9 $\mu \mathrm{m}$, while sheep erythrocytes have a mean diameter of $4.2 \mu \mathrm{m}$. Visually, the GPA-positive erythrocytes in samples from sheep 3419 and $3425 \mathrm{C}$ were found to have the same diameter as human erythrocytes. Flow cytometric measurements of light scatter, illustrated in Fig. 4, $d-f$, confirmed that the GPA-positive cells in sheep 3419 and $3425 \mathrm{C}$ had the same light scatter distribution as human cells. These results were all consistent with xenogeneic chimerism in the erythroid lineage in sheep 3419 and $3425 \mathrm{C}$. While the proportion of human erythrocytes was small ( 1.0 and $0.46 \%$, respectively), these cells appeared to be identical in size and GPA antigen presentation to normal human cells of MN blood type. Thus, the engrafted marrow appeared capable of producing mature terminally differentiated erythrocytes in the peripheral blood which maintained normal human size and antigenic composition.

Identification of human markers in myeloid and lymphoid cells. The presence of human cells in the myeloid and lymphoid lineages in blood and bone marrow of transplanted 
sheep at 15 months after transplantation was also documented using multivariate flow cytometric analysis of subpopulations labeled with monoclonal antibodies recognizing CD antigens present on human $\mathrm{T}$ cells (CD3, 4, and 5), natural killer and neutrophils (CD16), B lymphocytes (CD20), leukocytes (CD45), and immature myeloid and human stem cells (CD34).

Antibodies recognizing human forms of $\mathrm{CD}$ proteins showed minimal reactivity with sheep marrow or blood cells, with the exception of CD16, which appeared to label a minor subpopulation in control sheep marrow. In all cases, nucleated subpopulations in chimeric sheep tissues that were labeled with the CD-associated antibodies were sorted onto slides, and the actual frequency of human cells in the sorted population was quantitated after fluorescence in situ hybridization $(19,20)$ with biotinylated DNA probes specific for human repeated centromeric sequences $(20,21)$. Representative bivariate flow cytometric distributions of immunofluorescently labeled human marrow and marrow from sheep are shown in Fig. 5. CD34- and CD45-positive subpopulations are clearly visible in panels $a, c$, and $d$, and absent from the control sheep (panel $b$ ). The purity of the sorted immunofluorescence-positive subpopulations ranged between 45 and $93 \%$ (see Table IV legend for details). Data shown in Table IV reflect the frequency of human cells detected flow cytometrically corrected by the human cell fraction (quantitated by FISH) in the sorted subpopulations. The data show that both myeloid and lymphoid human cells were present in the peripheral blood and marrow of chimeric sheep. Marrow and blood of both sheep 3419 and 3425C contained CD34-positive subpopulations, as well as CD3-, CD4-, CD5-, CD16-, and CD20- positive leukocytes. Although flow cytometric analysis of CD8 immunofluorescence in chimeric sheep blood suggested the presence of CD8-
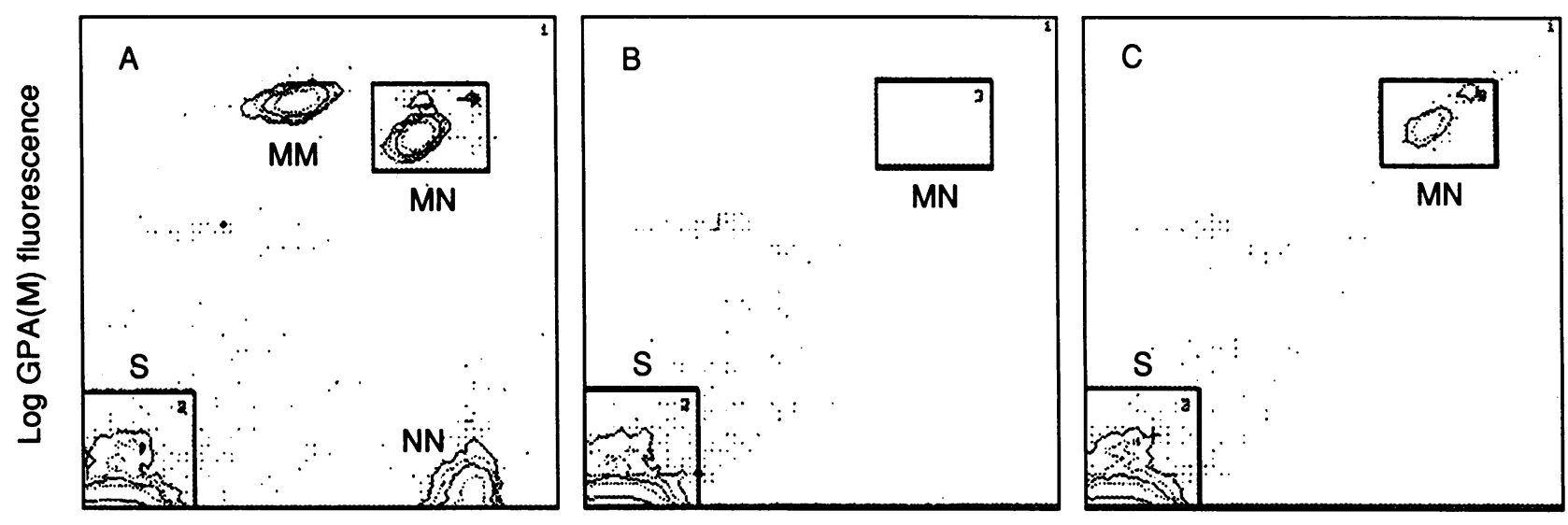

Log GPA(N) fluorescence
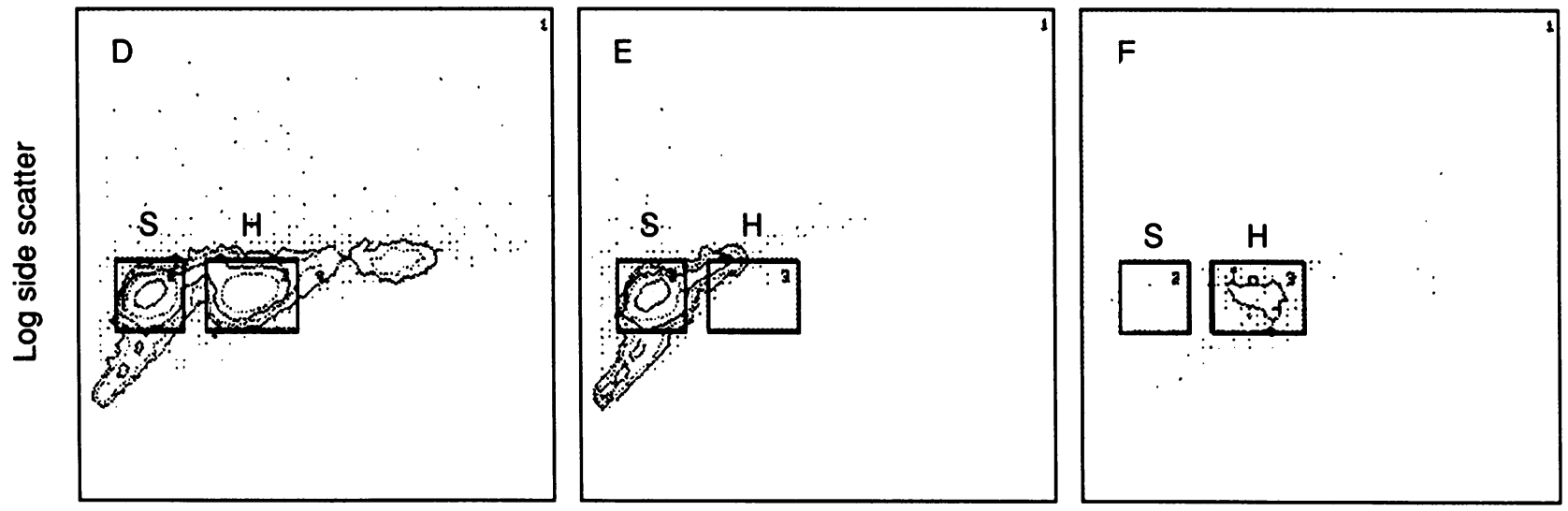

Forward light scatter

Figure 4. Flow cytometric analysis of sheep blood samples labeled with monoclonal antibodies specific for the human MN blood group antigens on erythrocytes. Blood cells were fixed with formaldehyde and labeled with two fluorescently tagged monoclonal antibodies. The antibody 6A7 labels the M-form of human GPA, while the antibody BRIC157 labels the N-form of GPA. The details of the fixation, labeling, and flow cytometry have been described previously $(17,18)$. All flow distributions show results from the analysis of 50,000 cells per sample with peaks indicated by logarithmic contour levels. Panels $A-C$ show immunofluorescence distributions with a logarithmic intensity scale along both axes. Panels $D-F$ show light scatter distributions with linear forward scatter ( $x$ axis) and log side scatter $(y$ axis). $(A)$ The fluorescence distribution from an artificial mixture of human and sheep cells containing $85 \%$ sheep erythrocytes and $5 \%$ each of human cells with MM, NN, and MN blood group phenotypes. $(B)$ Data from the analysis of normal sheep blood showing no positive labeling with either antibody. $(C)$ Data from the analysis of blood from one of the chimeric sheep (sheep 3419) showing a clear subpopulation of erythrocytes with the labeling characteristics of human cells with MN phenotype. $(D)$ Light scatter distribution of an artificial mixture of human (15\%) and sheep (85\%) erythrocytes showing that these two cell types differ in scatter due to differences in cell size. $(E)$ Light scatter distribution of the GPA-negative erythrocytes from the chimeric sheep 3419 showing a normal sheep pattern. $(F)$ Light scatter distribution of the GPA-positive erythrocytes from sheep B showing a human scatter pattern. 


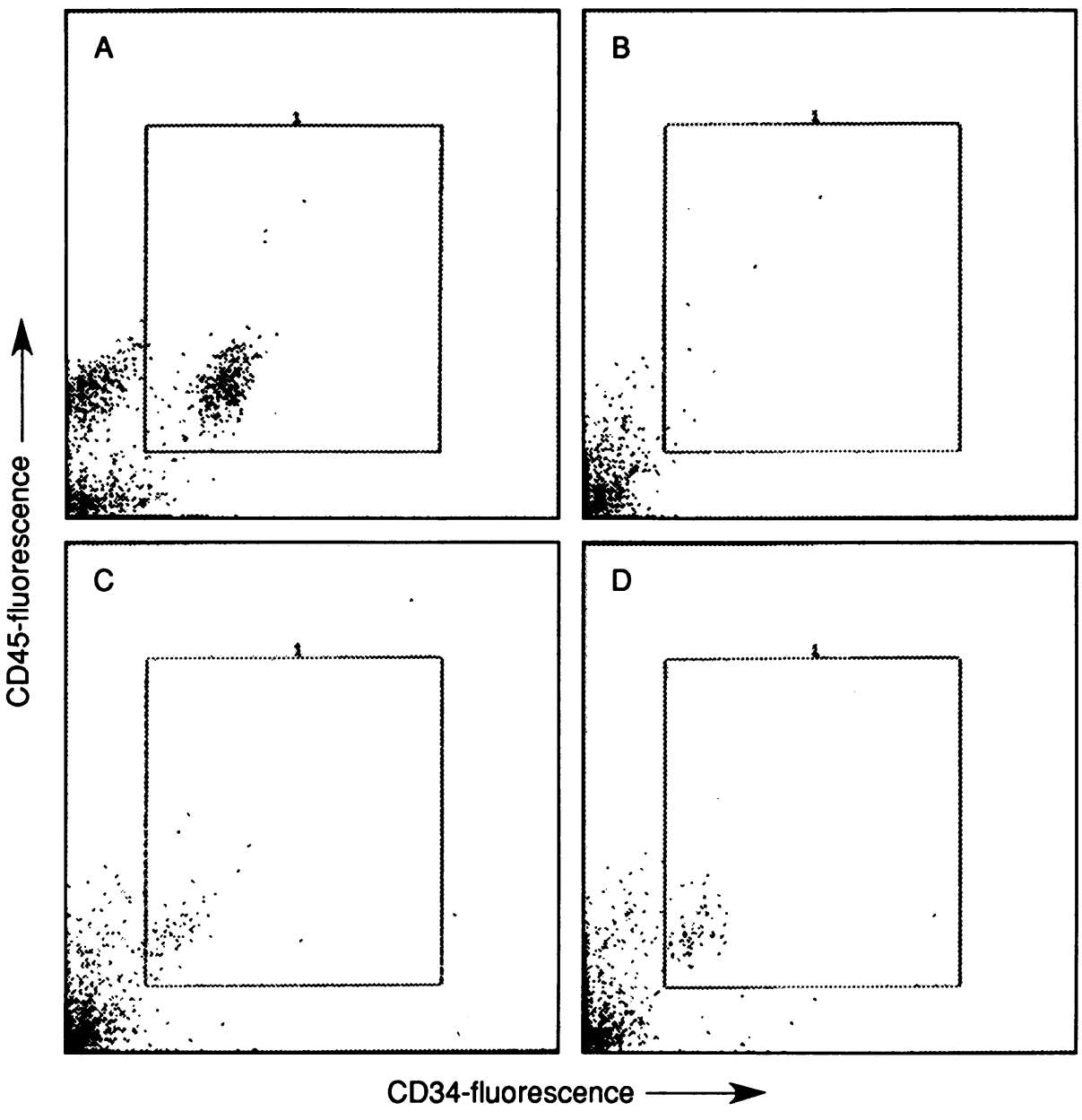

Figure 5. Bivariate distributions of immunofluorescently labeled marrow from human $(a)$, control sheep $(b)$, and chimeric sheep 3419 and $3425 C$ ( $c$ and $d$, respectively). Contaminating erythrocytes were removed from marrow by incubation in lysis buffer $(170 \mathrm{mM}$ $\mathrm{NH}_{4} \mathrm{Cl}, 0.1$ mM EDTA, $1 \mathrm{mM} \mathrm{KHCO}$, at $\mathrm{pH}$ 7.3), with successive washes in HBSS containing $0.02 \%$ sodium azide. Marrow samples were simultaneously labeled with FITC-conjugated antiCD34 (Dr. Peter Landsorp, Terry Fox Laboratories) and phycoerythrin-conjugated anti-CD45 (HLE-1; Becton Dicksinson Monoclonals). Briefly, each sample $(20 \mu \mathrm{g} / \mathrm{ml})$ was added to $5 \times 10^{5}$ cells. Samples were incubated in the presence of the antibody for $30 \mathrm{~min}$ at $4^{\circ} \mathrm{C}$, then washed twice in $5 \mathrm{ml}$ cold PBS without serum protein. The cells were then fixed $(0.1 \%$ paraformaldehyde in PBS, at pH 7.3) for 30 min at room temperature, washed once in cold PBS, and resuspended in cold PBS (with Hoechst 33342 at a concentration of $15 \mu \mathrm{M}$ ) for flow cytometric analysis. Analysis of bivariate phycoerythrin versus FITC-linked immunofluorescence profiles was performed using the system's FACStar ${ }^{\otimes}$ Plus Research software version 2.01 . positive cells, analysis of the sorted subpopulation by FISH indicated that human cells were not responsible for the apparent reactivity of chimeric sheep blood with anti-CD8. Thus, neither animal contained detectable levels of $\mathrm{T}$ cytotoxic/sup- pressor (CD8). Human cells present at a frequency of $0.1 \%$ can be detected by flow cytometric analysis of immunofluorescently labeled subpopulations (20). Thus, these data suggest that CD8-positive cells may not be involved in maintenance of

Table IV. Assessment of Donor (Human) Cell Engraftment in Chimeric Sheep by Flow Cytometry and FISH

\begin{tabular}{|c|c|c|c|c|c|c|c|c|}
\hline \multirow[b]{2}{*}{ Species } & \multirow[b]{2}{*}{ Tissue } & \multicolumn{7}{|c|}{ Human cell frequency (percent)* } \\
\hline & & $\mathrm{CD} 3$ & CD4 & CD5 & CD16 & CD20 & CD34 & CD45 \\
\hline \multirow[t]{2}{*}{ Sheep 3419} & Blood & $\mathrm{ND}^{\ddagger}$ & 1.8 & 0.5 & 2.3 & 0.4 & 1.6 & 3.5 \\
\hline & Marrow & 1.3 & 0.8 & 0.7 & 4.1 & ND & 0.9 & 10 \\
\hline \multirow[t]{3}{*}{ Sheep 3425C } & Blood & 1.8 & 1.3 & 0.5 & 1.9 & 0.6 & 0.73 & 2.5 \\
\hline & Marrow & 1.9 & 0.2 & 1.0 & 3.5 & ND & 0.65 & 16.3 \\
\hline & \multicolumn{7}{|c|}{ Relative Fractions (percent) ${ }^{8}$} & \\
\hline Human & Blood & 7.7 & 4.3 & 11 & 70.6 & 2.4 & 0.34 & \\
\hline Human & Marrow & 16.5 & 8.8 & 26.3 & 20.6 & 4.1 & 3.1 & \\
\hline \multirow[t]{2}{*}{ Sheep 3419} & Blood & ND & 50 & 14 & 65 & 11 & 46 & - \\
\hline & Marrow & 13 & 8 & 7 & 4 & ND & 9 & - \\
\hline \multirow[t]{2}{*}{ Sheep 3425C } & Blood & 72 & 52 & 20 & 76 & 24 & 29 & - \\
\hline & Marrow & 9 & 1 & 6 & 21 & ND & 4 & - \\
\hline
\end{tabular}

* Values represent the frequency of human subpopulations detected flow cytometrically after labeling with antibodies recognizing CD antigen and corrected by the actual frequency of human cells in the sorted subpopulations as measured using FISH. The average purity (percent) for each of the CD-positive antigen sorts was: CD3, 64; CD4, 73; CD5, 40; CD16, 69; CD34, 57; and CD45, 89. ${ }^{*}$ Samples not stained. ${ }^{8}$ Values represent the relative distribution of individual subpopulations in marrow and blood of human tissues and in the chimeras relative to the total leukocyte population (e.g., the CD45 fraction). The absolute fraction of CD45-positive cells in human blood and bone marrow was 93.2 and 83.4\%, respectively. The CD45-fractions of both chimeric sheep are shown in the upper portion of this table. 
tolerance in chimeric sheep, although this is by no means established.

The relative fraction of individual human subpopulations in sheep marrow and blood was compared with the distribution of similar subpopulations in human marrow and blood. Human marrow and blood was stained with the identical antibody panel used in the analysis of the chimeric sheep samples. All data were normalized to the fraction of the subpopulation which expressed CD45, a marker of all human leukocytes and lymphocytes with the exception of nucleated erythroid cells (Table IV). The CD34 fraction of marrow in chimeric sheep was three- to fourfold higher than in normal marrow. In blood of sheep 3419, CD34-positive cells comprised a remarkably high fraction $(46 \%)$ of the engrafted leukocytes. In contrast, human blood contained only $0.3 \%$ CD34-positive cells. Similarly, the frequency of CD4-positive cells in chimeric sheep is higher than found in human blood. The frequency of other chimeric marrow subpopulations is within a two- to fourfold range of similarly defined subpopulations in human marrow.

Thus, flow cytometric analysis and sorting of immunofluorescently labeled cells followed by FISH with human-specific DNA probes demonstrated that xenogeneic chimerism was achieved in three of the major hemopoietic lineages. Both mature and immature human cells were present, suggesting that the chimeric lineages contained a large complement of differentiated cells. Although the distribution of individual subpopulations within the engrafted hemopoietic system was not identical to that seen in normal human marrow and blood, the GPA erythrocyte data and the leukocyte cell surface markers suggested that the phenotypic and size characteristics resemble those of normal human cells.

Results presented in Fig. 6 show that, despite generally decreasing relative frequencies, donor cells continue to be present in bone marrow of all five, and blood of two chimeric lambs for up to two years after transplantation. Sheep 3425 , which at birth had exhibited donor cells in both marrow and blood, no longer shows human cells in the blood. Peripheral blood samples obtained from this animal beginning at 15 months after transplantation failed to show cells with human karyotype (Fig. 6). It is interesting to note that unlike the other four lambs which continue to exhibit all three human hemopoietic progenitor types (CFU-Mix, CFU-GM, BFU-E) in bone marrow, marrow from sheep 3425 develops only CFU-GM-derived colonies in vitro.

Effect of rHuIL-3 and GM-CSF on donor cell expression in chimeric lambs. The relative refractoriness of sheep hematopoietic progenitors to human IL-3 and GM-CSF is apparent from the data presented in Table V. With no additions to culture, modest numbers of myeloid and erythroid colonies were observed on day nine. These colonies were no longer present by day 19. This is characteristic of colonies formed by sheep bone marrow but not by human cells in this assay. However, when human-specific growth factors were added to the culture, while the colony counts were little changed on day 9 compared to control, numerous colonies were present on day 19 , suggesting the presence of viable human colony forming units. This was confirmed by karyotype analysis on day 19: all but one erythroid colony found on this day were composed entirely of human cells (Table V).

To assess whether this functional response could also be elicited in vivo in chimeric animals, we injected the long-term chimeric animals 3419,3425 , and $3425 \mathrm{C}$ with rHuIL-3 and $\mathrm{GM}-\mathrm{CSF}$ at $8 \mu \mathrm{g} / \mathrm{kg}$ twice daily for four days intravenously,
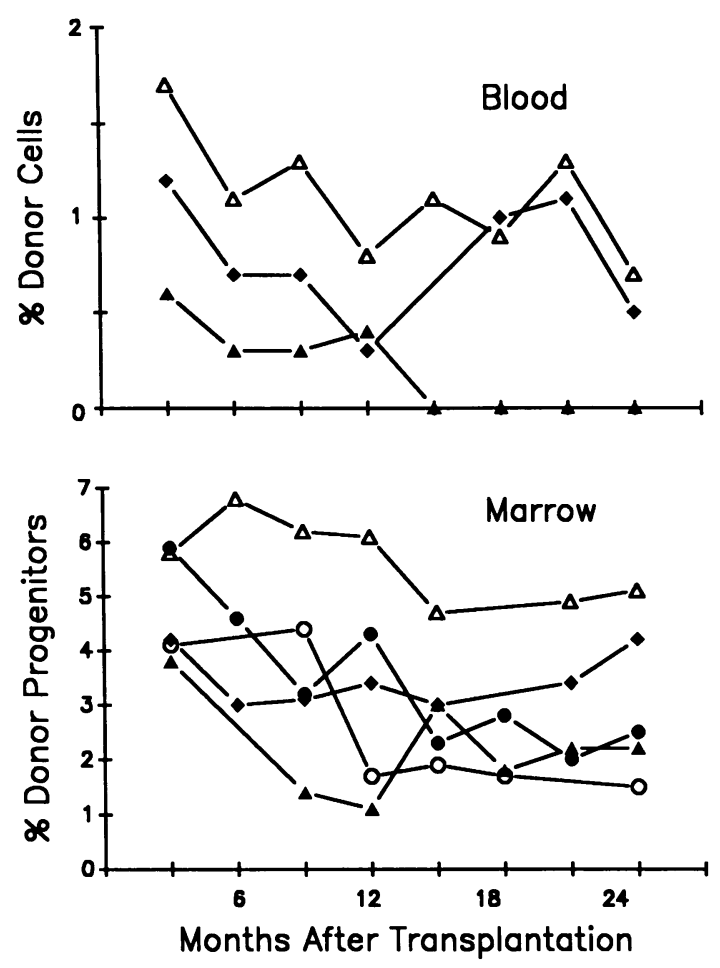

Figure 6. Persistence of donor (human) cells (blood)/progenitors (marrow) in chimeric sheep. Peripheral blood data are provided for the three animals that showed donor cells in circulation at birth. Bone marrow progenitors were assessed as described in text and legends to Fig. 3. - - 1219C; $0-0,1219 \mathrm{D} ; \Delta-\triangle, 3419 ; \Delta-\Delta$, $3425 ; \bullet-, 3425 \mathrm{C}$.

beginning 12 months after the original transplantation of human HSC. 24 hours after the last injection, bone marrow and peripheral blood were obtained and analyzed by karyotyping. These data are shown in Table VI. In all animals, four-day treatment with hematopoietic growth factors resulted in increases of 2.1 - to 3.4-fold in human cells in bone marrow aspirates, and an even larger increase in human cells in circulation (with the exception of sheep 3419).

These results were also confirmed by FISH. Experiments were done with identical protocols, but instead of karyotype analyses, blood and marrow samples were obtained after human growth factor stimulation and analyzed by FISH. The results are shown in Table VII. A Y chromosome-specific probe demonstrated a correspondingly high percentage of human cells in the blood and bone marrow of these sheep after

Table V. Effect of rHuIL-3/GM-CSF on Colony Formation by Chimeric Sheep (3419) Bone Marrow Cells in Vitro*

\begin{tabular}{lccccc}
\hline & \multicolumn{3}{c}{ Colonies/well } & & \\
\hline \multirow{2}{*}{$\begin{array}{c}\text { Additions to } \\
\text { culture }\end{array}$} & \multicolumn{2}{c}{ Myeloid $^{\ddagger}$} & & \multicolumn{2}{c}{ Erythroid } \\
\cline { 2 - 3 } \cline { 5 - 6 } None & Day 9 & Day 19 & & Day 9 & Day 19 \\
1L-3 & $6 \pm 3$ & 0 & & $19 \pm 7$ & 0 \\
GM-CSF & $4 \pm 2$ & $11 \pm 4$ & & $16 \pm 4$ & $7 \pm 1$ \\
& $7 \pm 3$ & $14 \pm 4$ & & $21 \pm 5$ & $8 \pm 2$ \\
\hline
\end{tabular}

* Cells $\left(4 \times 10^{4}\right.$ cells/well) were cultured with $2 \mathrm{IU} \mathrm{Epo/ml.}{ }^{\ddagger}$ Includes CFU-Mix-derived colonies. ${ }^{\$}$ All but one colony (from IL-3 cultures) exhibited human karyotype. 
Table VI. Effect of Treatment with Recombinant Human IL-3 and GM-CSF on the Relative Expression of Donor (Human) Cells in Chimeric Sheep*

\begin{tabular}{llllll}
\hline & \multicolumn{4}{c}{ Percent cells with human karyotype } \\
\cline { 2 - 3 } & \multicolumn{2}{c}{ Marrow } & & \multicolumn{2}{c}{ Blood } \\
\cline { 2 - 3 } Animal & Before & After & & Before & After \\
\hline 3419 & 6.1 & 13.2 & & 0.8 & 0.2 \\
3425 & 1.1 & 6.1 & 0.4 & 4.6 \\
$3425 \mathrm{C}$ & 3.4 & 11.8 & 0.3 & 4.9
\end{tabular}

* Bone marrow and blood samples were obtained from each animal before the start of treatment with IL-3/GM-CSF as described in text. ${ }^{\ddagger}$ Each value represents mean of results from quadruplicate preparations of two marrow aspirates (from different sites) and one blood sample from each animal and involved the examination of 720-1280 metaphases.

stimulation. This was additionally confirmed using a pan-centromeric human DNA-specific probe (data not shown). The relatively higher values obtained by FISH method (Table VII) probably reflect the fact that the procedure is more sensitive and detects all human cells, whereas karyotyping enumerates cells in metaphase only (Table VI).

\section{Discussion}

This work establishes the feasibility of engrafting human fetal HSC onto the bone marrow of a large animal by in utero transplantation approach. Engrafted cells are not only retained, but are capable of multilineage differentiation into cells bearing human surface markers, human karyotype, and in vivo response to human-specific growth factors. As judged by karyo-

Table VII. Effect of Treatment with Recombinant Human IL-3 and GM-CSF on the Relative Expression of Donor (Human) Cells in Chimeric Sheep*

\begin{tabular}{clc}
\hline Sheep & Sample analyzed & $\begin{array}{c}\text { Donor (human) } \\
\text { cell frequency }\end{array}$ \\
\hline \multirow{3}{*}{ Control } & Blood & Percent \\
& Marrow & 0 \\
3419 & Blood & 0 \\
& Marrow & 20 \\
$3425 C$ & Blood & 20.8 \\
3425 & Marrow & 9.3 \\
& Blood & 12.8 \\
& Marrow & 8.9 \\
& & 27.8
\end{tabular}

\footnotetext{
* Bone marrow and blood samples were obtained from each animal 24 hours after the last injection of rHuIL-3/GM-CSF and analyzed by FISH. " The frequency of human cells was determined microscopically by scoring 100 cells showing species-specific hybridization domains after FISH with a DNA probe showing homology to alpha satellite repeated DNA sequences located at or near human centromere (see text). Compare the data with those in Table VI where the frequency of human cells in blood and marrow of the same animals are given before treatment, using karyotyping.
}

typing technique, at least $40 \%$ (13 of 33 ) of recipients were chimeric at some point after transplantation. Long-term chimerism was also documented in those animals that were followed for at least two years. Karyotyping, however, depends on the often fortuitous finding of metaphase plates, and thus underestimates the true degree of chimerism. Hence, $40 \%$ should be considered a highly conservative estimate of the degree of chimerism achieved.

Engraftment of human hemolymphoid cells in a xenograft system has been achieved by several groups (4-10). Both irradiated mice (4) and genetically immunodeficient mice (5-10) have served as recipients. Initially, the reconstitution of lymphoid lineages was noted and the expression was of rather transient nature $(5,7)$. Reconstitution for at least six months was also reported by Mosier et al. (6) and by Namikawa et al. (10) who observed reconstitution of human multilineage hemopoiesis in mice lasting for a period of 5-11 months.

Functional potential of engrafted cells has been documented in most studies (8). Transfer of autoimmune disease has been accomplished by the transfer of lymphocytes from patients with primary biliary cirrhosis into severe combined immunodeficient mice (8). Human antibody response to dinitrophenol has been observed by Lubin et al. (4) after primary and secondary immunization (4).

Generally, immunodeficient mice have been the preferred recipients for engraftment of human HSC. This is due to the fact that irradiated mice retain some natural killer cells and lymphocyte-activated killer cells that form a barrier to the growth of human cells $(23,24)$. On the other hand, immunodeficient mice poorly engraft or differentiate into $T$ cells unless thymic epithelium is also implanted under the kidney capsule $(5,10)$. In this regard, preimmune fetuses can overcome both of these barriers.

The feasibility of this xenograft system is derived from the fact that both donors and recipients are immunologically naive and exceptionally tolerant of each other. Donor cells are derived from 12-15-week-old human fetuses, whereas the immunological system in humans develops between 12 and 20 weeks of gestation $(11,25)$. Thus, the possibility of donor cells reacting against the recipient animal in a GVH type of reaction is minimized. On the other hand, the recipients, being less than eight-week-old fetuses, are also preimmune (26) and incapable of graft rejection that would otherwise be expected. In this context the use of xenogeneic grafting is particularly desirable, since, in general, the immune response to xenograft is weaker than that of allogeneic response (27).

The possibility of making preimmune fetuses tolerant of otherwise immunologically incompatible cells has been evident since the work of Owen in 1945 (28) who anastomosed placentae of bovine dizygotic twins. This led to long-term retention of red cells of dizygotic origin in both twins. Parabiosis in chick embryos $(29)$ and other works $(30,31)$ subsequently confirmed this experiment. Billingham et al. (32), in a classic work, were then able to actively induce acquired tolerance in mice by in utero introduction of unrelated cells. Similar observations have been subsequently reported by others, including our own groups in other species in both allogeneic and xenogeneic systems $(4-10,12-14,26,33)$. The frame of reference is thus both long-standing and wide. In a postnatal setting, tolerance is generally induced by conditioning regimens such as ionizing radiations and/or cytoablative therapy $(1,2)$. This treatment not only overcomes the immunological barrier, but also depletes the endogenous stem cell pool and permits ready 
expansion of donor HSC pool which can now occur without competition (1, 2). By contrast, HSC engraftment in the fetus occurs without the need for conditioning regimens (12-14).

In addition to immunological tolerance afforded by the preimmune status of the fetus, fetal transplantation offers a unique setting for engraftment of exogenous sources of HSC. The uniqueness is derived from the predictable switch in the sites of hemopoiesis during ontogeny. During the embryonic and fetal life, hemopoiesis moves consecutively from yolk sac to liver/spleen and then to the bone marrow (reviewed in references 34-37). With the exception of the early embryonic period when the yolk sac is hemopoietic, during most of the fetal life hemopoiesis is a function of liver/spleen. During the latter part of gestation, bone, and consequently, marrow, spaces begin to develop and expand. HSC then migrate from liver/ spleen to the marrow in a steady, continuous fashion. They occupy hemopoietic sites or "niches" in the developing marrow which is now ready to accommodate their homing and proliferation (38). During this period when an exogenous source of HSC is introduced in the fetus, particularly in a large dose (single or multiple), these cells can effectively compete with those of the endogenous sources for homing and engraftment to the marrow (39). However, unless the transplanted HSC are introduced in a continuous, steady fashion, competing native HSC may gain a competitive edge. This may explain our observation that in certain cases the relative proportion of cells with human markers is subsequently reduced in the marrow even though the total pool of these human cells may expand with the growth of marrow cavities. Repeated transplantation of exogenous HSC over a period of time may regain the competitive edge for these cells.

Our data presented here are consistent with the view that although during the latter part of gestation, marrow hemopoietic sites expand and are primed to receive migrating HSC (exogenous or endogenous), the contribution of marrow to the formation of circulating blood cells is negligible, if any. This is evident from the observation that no circulating cells with human markers were noted during this period, despite their presence in the bone marrow. Cells with human markers appear in the blood only during the perinatal period when liver ceases to be hemopoietic and bone marrow assumes this function. In the interim, engrafted HSC may remain in the marrow and undergo proliferation without significant differentiation. This can only lead to the expansion of HSC pools (both exogenous and endogenous) parallel to the expansion of marrow cavities (34-36).

Certain maneuvers may provide the donor HSC pool with a competitive edge, thus enhancing the success in transplantation. The dose of given HSC may be one such factor. In the present work, this could not be well-controlled for, because of the use of aborted human fetuses. However, studies using allogeneic fetal transplantation in sheep and monkeys (12) suggest a dose-dependence in engraftment success. Increasing the cell dose may then provide a higher proportion of cells engrafted. In this regard, fractionation and concentration of HSC in vitro, before infusion, may also be helpful.

Another factor could be the optimal time and dose schedule during the gestation period when homing of donor cells could be maximized relative to the intrinsic pool of HSC. This requires an extended time course study with well-controlled doses of transplanted cells.

Another maneuver, addressed in the present study, is the use of species-specific growth factors. The data presented here clearly demonstrate that sheep HSC are not responsive to the concentrations of human recombinant growth factors used here. Similar species specificity has been documented for IL-3 in human and mice (40). Such growth factors could provide donor cells with a competitive edge when used in vivo after transplantation. Thus, the pool of donor cells could be induced to expand by the use of rHuIL-3 and rHuGM-CSF, irrespective of the method of detection (karyotyping, FISH, etc.). In this regard, the use of other recombinant growth factors deserves consideration, since they may provide means of manipulating the engraftment and proliferative capacity of donor cells. We have shown that in adult murine system, a brief in vivo incubation of donor cells, before transplantation, can increase the density of homing receptors on the cell surface and subsequently enhance the grafting ability of these cells (15). A similar maneuver has also been successful in allogeneic transplantation in the fetal system (41) and may be worthy of consideration in xenogeneic transplantation as well. By contrast, using a pump system in immunodeficient mice, rHuGM-CSF and IL-3 did not increase the number of engrafted macrophage colonies (7), giving rise to the suggestion that engrafted human cells may provide their own growth factors. An alternative interpretation would be that macrophage colonies may behave differently in their response to growth factors in this setting.

Proliferation and sustenance of donor HSC require the use of humoral and cellular machinery of bone marrow stroma which is provided by the recipient. The responsiveness of donor cells to species-specific growth factors suggests that, in this xenograft system, donor cells may not fully integrate into the recipient's marrow stroma. That engraftment and cellular proliferation of donor cells occur at all, raises a fundamental question in HSC transplantation. It is possible that stromal cells are transplanted along with HSC and these elements can be used by donor cells to provide species-specific cellular and humoral machinery for hemopoietic cellular proliferation. There exists some evidence in the literature for stromal cell transplantability (42).

The xenograft system, described here, may offer several potential applications. First, it can serve as a technique for assaying engraftment potential of human HSC. In the mouse, transplantability can be measured by colony-forming assay in spleen (43). In the human system, however, only the number of HSC can be estimated in vitro by CFU-Mix assay. This assay may not bear a relationship to their transplantability which relates to specific cell surface receptors $(44,45)$.

In addition, the xenograft system can serve as a means of in vivo storage and/or expansion of human HSC. Certain expansion of donor HSC occurs as the bone marrow tissue expands during the latter part of the fetal development. Further expansion can be induced by the in vivo use of human recombinant growth factors. Subsequently, human cells can readily be separated and recovered from sheep cells by virtue of their specific surface molecules (CD antigens) that are not expressed in sheep. Hence, sheep or similar large animals can serve as a convenient reservoir of human HSC, until such time as the cells are needed.

In this regard, it should be mentioned that our present data demonstrate that human cells in the host animals are capable of differentiating into lymphoid cell lines. This potential may allow them to respond to certain antigens and the production of human immunoglobulins which could subsequently be recovered from the serum by affinity techniques, using antihuman Ig antibodies. Thus, the system may be potentially a 
source of production of human immunoglobulins as well. Realization of these theoretical potentials all require further studies.

Finally, in utero transplantation of hemopoietic cells, per se, offers a new realm of possibilities, otherwise not attainable by the existing techniques in postnatal setting: with the availability of procedures for prenatal diagnoses of many genetic disorders, the possibility of in utero therapeutic intervention for the correction of many genetic defects can now indeed be realized by the introduction of normal HSC $(46,47)$. In utero intervention precludes potential rejection and GVHD, otherwise expected in a postnatal setting.

\section{Acknowledgments}

This work was supported by National Institutes of Health grants HL46556, HL-40722, DK30142, and AI27909, by the Department of Veterans Affairs, by U. S. Department of Energy Contract W-7405-ENG48, and by the G. Harold and Leila Y. Mathers Charitable Foundation.

\section{References}

1. Sullivan, K. M. 1989. Current status of bone marrow transplantation. Transplant. Proc. 21(Suppl. 1):41-50.

2. O'Reilly, R. J., C. A. Keever, T. N. Small, and J. Brochstein. 1990. The use of HLA-nonidentical T cell depleted marrow transplants for correction of severe combined immunodeficiency disease. Immunodefic. Rev. 1:23-30.

3. Flake, A. W., M. R. Harrison, and E. D. Zanjani. 1991. In utero stem cell transplantation. Exp. Hematol. (NY). 19:1061-1064.

4. Lubin, I., Y. Faktorowich, T. Lapidot, Y. Gan, Z. Eskhar, E. Gazit, M. Levite, and Y. Reisner. 1991. Engraftment and development of human T and B cells in mice after bone marrow transplantation. Science (Wash. DC). 252:427431.

5. McCune, J. M., R. Namikawa, H. Kameshima, L. D. Shultz, M. Lieberman, and I. L. Weissman. 1988. The SCID mouse: murine model for the analysis of human hematolymphoid differentiation and function. Science (Wash. DC). 241:1632-1639.

6. Mosier, D. E., R. J. Gulizia, S. M. Baird, and D. B. Wilson. 1988. Transfer for a functional human immune system to mice with severe combined immunodeficiency. Nature (Lond.). 335:256-259.

7. Kamel-Reid, S., and J. E. Dick. 1988. Engraftment of immune-deficient mice with human hematopoietic stem cells. Science (Wash. DC). 242:1706-1709.

8. Krams, S. M., K. Dorshkind, and E. M. Gershwin. 1989. Generation of fibrillary lesions after transfer of human lymphocytes into severe combined immunodeficient (SCID) mice. J. Exp. Med. 170:1919-1930.

9. McCune, J. M., R. Namikawa, C. C. Shih, L. Rabin, and H. Kameshima. 1990. Suppression of HIV-infection in AZT-treated SCID-hu mice. Science (Wash. DC). 247:564-566.

10. Namikawa, R., K. N. Weilbaeker, H. Kameshima, E. J. Yee, and J. M. McCune. 1990. Long-term human hematopoiesis in the SCID-hu mouse. J. Exp. Med. 172:1055-1063.

11. August, C. S., A. I. Berkel, S. Driscoll, and E. Merler. 1971. Onset of lymphocyte function in the developing human fetus. Pediatr. Res. 5:539-547.

12. Zanjani, E. D., F. R. MacKintosh, and M. R. Harrison. 1991. Hematopoietic chimerism in sheep and nonhuman primate by in utero transplantation of fetal hematopoietic stem cells. Blood Cells (NY). 17:349-363.

13. Flake, A. W., M. R. Harrison, N. S. Adzick, and E. D. Zanjani. 1986. Transplantation of fetal hematopoietic stem cells in utero: the creation of hematopoietic chimeras. Science (Wash. DC). 233:766-778.

14. Harrison, M. R., T. M. Crombleholme, A. F. Tarantal, R. N. Slotnick, M. S. Golbus, and E. D. Zanjani. 1989. In utero transplantation of fetal liver haematopoietic stem cells in monkeys. Lancet. ii:1425-1427.

15. Tavassoli, M., M. Konno, Y. Shiota, E. Omato, J. J. Minguell, and E. D. Zanjani. 1991. Enhancement of grafting efficiency of transplanted marrow cells by preincubation with interleukin-3 and granulocyte-macrophage colony stimulating factor. Blood. 77:1599-1606.

16. Ash, R. C., R. A. Detrick, and E. D. Zanjani. 1981. Studies on human pluripotential stem cells (CFU-GEMM) in vitro. Blood. 58:309-316.

17. Langlois, R. G., B. A. Nisbet, W. L. Bigbee, D. N. Ridinger, and R. H. Jensen. 1990. An improved flow cytometric assay for somatic cell mutations at the glycophorin A locus in humans. Cytometry. 11:513-521.

18. Langlois, R. G., W. L. Bigbee, and R. H. Jensen. 1985. Flow cytometric characterization of normal and variant cells with monoclonal antibodies specific for glycophorin. Am. J. Immunol. 134:4009-4017.

19. Weier, U., J. N. Lucas, M. Poggensee, R. Segraves, D. Pinkel, and J. W. Gray. 1991. Two-color hybridization with high complexity chromosome-specific probes and a degenerate alpha satellite probe DNA allows unambiguous discrimi- nation between symmetrical and asymmetrical translocations. Chromosoma (Berl.) 100:371-376.

20. Pallavicini, M. G., R. G. Langlois, M. Reitsma, M. Gonzalgo, D. Sudar, T. Montoya, H. U. Weier, and S. Haendel. 1992. Comparison of strategies to quantitate uniquely marked cells in intra- and interspecies hemopoietic chimeras. $\mathrm{Cy}$ tometry. In press.

21. Pallavicini, M. G., P. DeTeresa, and F. M. Wurm. 1990. Effects of methotrexate on transfected DNA stability in mammalian cells. Mol. Cell. Biol. 10:401404.

22. Johnson, G. D., and J. G. M. de C. Noguieie. 1981. A simple method of reducing the fading of immunofluorescence during microscopy. J. Immunol. Methods. 43:349-350.

23. Dorshkind, K., S. B. Pollack, M. J. Bosma, and R. A. Phillips. 1985. Natural killer (NK) cells are present in mice with severe combined immunodeficiency (SCID). J. Immunol. 134:3798-3801.

24. Fostad, O., C. T. Hansen, G. B. Cannon, C. N. Statham, G. R. Lichenstein, and M. R. Boyd. 1984. Lack of correlation between natural killer activity and tumor growth control in nude mice with different immune defects. Cancer Res. 44:4403-4408.

25. van Furth, R., H. R. E. Schuit, and W. Hijmans. 1965. The immunological development of the human fetus. J. Exp. Med. 122:1173-1187.

26. Silverstein, A. M., R. A. Prendergast, and K. L. Kraner. 1963. Fetal response to antigenic stimulus. II. Antibody production by the fetal lamb. J. Exp. Med. 117:799-812.

27. Auchincloss, H. 1988. Xenogeneic transplantation. Transplantation (Baltimore). 46:1-20.

28. Owen, R. D. 1945. Immunogenetic consequences of vascular anastomoses between bovine twins. Science (Wash. DC). 102:400-401.

29. Hasek, M. 1953. Parbiosis of birds during embryonic development. Cesk. Biol. 2:265-270.

30. Felton, L. D. 1949. The significance of antigen in animal tissues. J. Immunol. 61:107-117.

31. Dunsford, I., C. C. Bowley, A. M. Hutchinson, J. S. Thompson, R. Sanger, and R. R. Race. 1953. A human blood-group chimera. Br. Med. J. ii:81.

32. Billingham, R. E., L. Brent, and P. B. Medawar. 1953. Actively acquired tolerance of foreign cells. Nature (Lond.). 172:603-606.

33. Binns, R. M. 1967. Bone marrow and lymphoid cell injection of the pig foetus resulting in transplantation tolerance or immunity, and immunoglobulin production. Nature (Lond.). 214:179-181.

34. Metcalf, D., and M. A. S. Moore. 1971. Embryonic aspects of hemopoiesis. In Frontiers of Biology-Hematopoietic Cells. A. Neuberger and E. L. Tatus, editors. North Holland Publishing Co., Amsterdam. 172-271.

35. Tavassoli, M. 1991. Embryonic and fetal hemopoiesis: an overview. Blood Cells (NY). 17:269-281.

36. Tavassoli, M. 1991. Ontogeny of hemopoiesis. In CRC Handbook of Human Growth and Developmental Biology. Vol. III, part A. E. Mersami and P. Timeras, editors. CRC Press, Inc., Boca Raton, FL. 101-112.

37. Tavassoli, M., and J. J. Yoffey. 1983. Bone marrow: structure and function. Alan R. Liss, Inc., New York.

38. Trentin, J. Hemopoietic microenvironment: historical perspective, status, and projection. 1989. In Handbook of Hemopoietic Microenvironment. M. Tavassoli, editor. Humana Press Inc., Clifton, NJ. 1-86.

39. Tavassoli, M., and C. L. Hardy. 1990. Molecular basis of homing intravenously transplanted cells to the marrow. Blood. 76:1059-1070.

40. Yang, Y. C., A. B. Ciarletta, P. A. Temple, M. P. Chung, S. Kovacic, J. S. Witek-Gianmotti, A. C. Leary, R. Kriz, R. E. Donohue, G. G. Wong, and S. C. Clark. 1986. Human IL-3 (multi CSF): identification by expression cloning of a novel hematopoietic growth factor related to murine IL-3. Cell. 47:3-10.

41. Zanjani, E. D., M. R. Harrison, and M. Tavassoli. 1990. Enhancement of engraftment of in utero transplanted fetal liver hematopoietic stem cells. Blood. 176:173a. (Abstr.)

42. Anklesaria, R., K. Kase, G. Glowacki, C. A. Holland, M. A. Sakakenny, G. A. Wright, T. J. Fritzgerald, C. Y. Lee, and J. S. Greenberger. 1987. Engraftment of a clonal bone marrow stromal cell line in vivo stimulates hematopoietic recovery from total body irradiation. Proc. Nat. Acad. Sci. USA. 84:76-81.

43. Till, J. E., and E. A. McCullock. 1961. A direct method of measurement of the radiation sensitivity of normal bone marrow cells. Radiat. Res. 14:213-222.

44. Brandt, J., E. F. Srour, K. van Besien, R. A. Briddell, and R. Hoffman. 1990. Cytokine-dependent long-term culture of highly enriched precursors of hematopoietic progenitor cells from human bone marrow. J. Clin. Invest. 86:932-941.

45. Verfaillie, C., K. Blakolmer, and P. MoGlave. 1990. Purified primitive human hematopoietic progenitor cells with long-term in vitro repopulating capacity adhere selectively to irradiated bone marrow stroma. J. Exp. Med. 172:509520 .

46. Zanjani, E. D., P. W. Kantoff, D. Ekhterae, S. Bond, L. C. Lasky, M. R. Harrison, and W. F. Anderson. 1987. In Clinical Applications of Genetic Engineering. L. C. Lasky and J. M. Edward-Moulds, editors. American Association of Blood Banks, Arlington, VA. 47-57.

47. Touraine, J. L. 1991. In utero transplantation of fetal liver stem cells in humans. Blood Cells (NY). 17:379-387. 